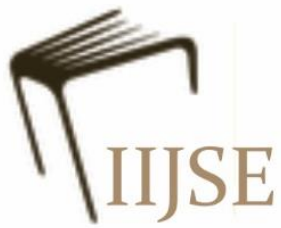

\title{
LALABET FINANCIAL ANALYSIS: STUDY OF ISLAMIC ECONOMICS AT MICRO LEVEL
}

\author{
Ainorrofiqie $^{1}$ \\ Universitas Islam Negeri Maulana Malik Ibrahim Malang \\ afiazizie@gmail.com \\ Umrotul Khasanah ${ }^{2}$ \\ Universitas Islam Negeri Maulana Malik Ibrahim Malang \\ umrotul_kh@yahoo.com
}

\author{
Ahmad Djalaluddin ${ }^{3}$ \\ Universitas Islam Negeri Maulana Malik Ibrahim Malang \\ djalaludin@akuntansi.uin-malang.ac.id
}

\begin{abstract}
This research aims to explore the model of financial management tradition Lalabet in the village of Babbalan District Batuan Sumenep. This study is based on the fact that occurred in the community about the implementation of traditions carried out by the heirs to family members who died. Interpretative qualitative research is used and an in-depth understanding of a problem that occurs is emphasized more. Based on the results of this study, the financial management tradition Lalabet can be done based on accounting equations. The accounts contained in the accounting equation is not used in its entirety and are reported as are generally financial statements. In this case, the source of funds in carrying out Lalabet tradition is sourced from personal money, money and donations from the family, money from Muslimat, debt, and money or goods from Lalabet's proceeds. The impact is the onset of debt both short-term and long-term. While the expenditure is in the form of costs in taking care of the body, costs for tahlilan (petto'arean), pa'polo, nyatos, nyataon, nyaebu, mangaji, ngin-tangin, nyalenin mayyid, and ajege makam (kep-sekep).
\end{abstract}

Keywords: Finance, Lalabet, Tradition and Accounting 


\section{INTRODUCTION}

Madura people are not only rich in arts and culture but also known as a tolerant and religious society. The majority of Muslims living there are devout adherents of Islam. These two things, religion and culture ultimately do acculturation that does not eliminate each other. Islamic teachings are dialectical with the local culture eventually formed a variant of Islam that is distinctive and unique in Madura. This variant of Islam is not Islam divorced from its purity roots, but Islam in which it has been cultured with local culture. Islam remains undivided ideological roots, as well as the local culture is not necessarily lost with the inclusion of Islam in it.

The result of Islamic acculturation with local culture persists for generations until it becomes a tradition that remains carried out in Madura society. The majority of Madurese people perform congratulations events ranging from marriage, birth to death. In each event the congratulations always bring together the local culture with the belief (religion) of Islam. In the event of death for example, in addition to the obligation to carry out fardu kifayah, namely bathing, disprobating and burying bodies, the community in Babbalan Village also has an obligation to fulfill the Lalabet tradition.

The implementation of Lalabet tradition in Babbalan Village can be said to be unique because it has its own peculiarities. Lalabet tradition almost has the same meaning as Takziyah (Islam) or Lelalu (Java), namely to visit a family that is being affected by the death. Although both intend to visit the family that is being affected by the death, but Lalabet has a different implementation. Takziyah (Islam) or Lelalu (Java) is done by men and women carrying envelopes containing money on the day of death, while Lalabet is done by men and women, where the eves generally come with food in the form of rice although there is a small percentage of them give money because they do not have time to buy rice. In addition, community donations can be in the form of coconut, vegetables, fruits, coffee and granulated sugar. All kinds of foodstuffs are intended to ease the burden of grieving families in every event of death. In return the host did not forget in every dive of death the mourners were served food and provided with rice to take home with the aim of honoring the guests who mourned including intended in order to give alms whose reward is reserved for the dead. 
At the stage of Lalabet, the procession is not only done on the night of death, but done until the seventh day or pettong are. People who are unable to attend on the day of death or first, can do Lalabet on the second day, until the seventh day. Where generally the most crowded time for Lalabet is on the first day (saarena), the third day (loktellok) and the seventh day (tokpettok). The reason for these moments Lalabet guests crowded because it coincides with the recitation of verses of the-Qur'an and prayers known as tahlilan events. Tahlilan events are conducted by men, where wives generally join with their husbands. The wives came with the aim of Lalabet, and will return home after her husband has finished dhikr and berhlil.

Unwittingly, in the implementation of Lalabet tradition in Madura is inseparable from the economic process in it. Uniquely, in the tradition of Lalabet can be seen from the obligation of each family member to do the same. In accounting, such an event can be likened to debt and receivables, where there are two parties who give and receive it. In the tradition of death ceremony in Madura, the debt in question can be in the form of shortterm debt (in this case the time of return is very short from the public's gift to the heirs because the relative in question died not long from the incident) and long-term debt (the return is quite long and very long because relatives of the community in question have not died). In addition, the recognition of the present value is not equal to the future value even in the same form or goods, this also happens in the implementation of the Lalabet tradition where goods are given or donated by relatives today and must be returned in the future with a value that is not the same as the present value or madurese give the term with adagium "Tengka".

Researchers know the thickness of the term Tengka can be found in the daily life of the people of Babbalan Village, Batu District, Sumenep. The villagers have a high level of sympathy and empathy in this incident. As in the case of this death, Babbalan people will flock and join together to balance the funeral home as a form of their grief, encourage the grieving family indirectly, and help relieve the grieving family about the costs that will be incurred by the heirs in carrying out the Madurese customary death ceremony. Because for the people of Babbalan, the loss of relatives experienced by grieving families is the same as the loss of their own relatives. This can be known by the level of participation of the community in assisting the implementation of the death ceremony. The complexity of 
Babbalan villagers in undergoing the tradition procession "Lalabet" attracted attention to be studied. The author tries to uncover about how financial management in the tradition of Lalabet happened in Babbalan village. So, it is not expected in the purpose of this research, the model of financial management in the tradition of Lalabet can be elaborated more and more seen in sharia perspective.

\section{REVIEW OF LITERATURE}

In social life accounting is found, using term that is still simple and not scientific, such as expenditure and income. The narrow understanding of accounting in social life is driven by the fact that the understanding of accounting around the point focuses on techniques and calculations

Accounting is not enough to focus on the orientation of science because there is substantially art contained in it. Thus, in the development of accounting is influenced by several things such as cultural value, economic sector, law and regulation, system, social and political where accounting develops (Suwardjono, 2011).

In accounting, cultural value in turn began to get the attention of many scientists. As previously researched, accountability is based on local values in Javanese culture. His study found the concept of obah-mamah-sanak, this concept is used as a basic concept of cash flow, also as an excess of balance value (Zulfikar, 2008).

Another research, related to the combination of accounting with local values Subak, Bali (Saputra 2011). Other than that, as well as other research, related to changing the local value of Toraja culture in building public sector accountability, Kombongan (a discussion held to solve the problem) is a reconstruction between input accountability and output accountability (Randa and Daromes 2014). Other fields related to accounting for the Islamic culture of Gorontalo (Mohammad Anwar Thalib 2017). The last related research is also Tracing Accounting in Javanese Tradition (Ari Kamayanti 2019).

\section{RESEARCH METHOD}

The researchers decided in this study to use a type of interpretive qualitative research, which emphasizes more on the aspects of deep understanding of Lalabet traditions that occur. Systematically analyzing the social action that occurred in Madura 
society regarding financial management in Lalabet tradition. In addition, this type of qualitative research is widely used by researchers to find out things that are not yet known by science (Lexy J. Moleong 2016).

In supporting this, researchers used ethnographic methods that can be applied in collecting empirical data on culture and society. That culture and society can be revealed in several ways such as simple comments and interviews (James P. Spradley 2016).

Then the results of the ongoing process is systematically compiled to improve understanding of the data found to be reported (Bogdan \& Biglen 1982).

\section{RESULTS AND DISCUSSION}

\section{Madurese Death Financial Management Model}

The financial management model of Madura traditional Lalabet tradition, ranging from funding sources, costs incurred, to pay obligations arising from the implementation of the Lalabet tradition. Please know how the financial flow that occurs in this tradition, as a form of accountability Mr. Nawir Ibrahim for the continuity of the tradition Lalabet Madura customs implemented.

In contrast to the tradition of marriage, where there is preparation in the issue of funding. In Lalabet tradition, preparations for fundraising are very small due to the age of man no one knows and the time of occurrence is sudden. As the result of the interview with Mr. Nawir Ibrahim as Mr. Nawir Ibrahim in raising funds to carry out this Lalabet tradition:

"Dhek kadekna engko gitak roserroan nginjem pesse, andikna dhibi' lun eangguy, bile kalagguenna korang ye polana e disa la tradisi, ye ngalak aki aotang e toko"

("The first time I have not looked for debt, so the money itself used to be used for this tradition, for the next if less because this is already the tradition in the village, I owe first in the store").

K. Atrawi in his statement:

"Biasana tatangge se aberrik otangan, mon se kaprah genika. Bedha jugen sombangan dhari tretan se ikhlas aberrik obheng otabe nyombeng bhereng-bhereng akadhi nase', minnyak, tellor, palappa, ban salaenna" ("Usually neighbors who give debts, like that. 
There are also donations from families who are willing to give money or donate goods such as rice, oil, eggs, seasonings and others").

In this Lalabet tradition, financial management is budgeted in a short time, meaning that if the first day of Lalabet tradition implementation of funds is sufficient, then the funds on the first day are budgeted for expenditure on the first day. On the second day, if there is still remaining funds on the first day then the funds are budgeted for expenses on the second day and the rest can be obtained by means of debt and so on. In the community of Babbalan Village, there is a gathering of mothers known as Muslimat NU. This becomes a routine for mothers every Saturday afternoon, a type of arisan which is filled with recitation. One of the policies is to provide an early amount of funds for members whose families have been affected by the disaster. Thus, the source of funds in the Lalabet tradition can be obtained from the association as long as the concerned has not received any funds at all before. And instead our name will no longer get the funds afterwards.

In Lalabet's financial management, record keeping is not done all. Only on donations made to Mr. Nawir Ibrahim by their relatives and loans from took as well as people. In the case of expenses, no written recording is made. Here is the flow of funds obtained and issued in the tradition of Lalabet Madura customs:

Assets (term from researchers) obtained through private money owned by Mr. Nawir Ibrahim on the first day of the family there died. Additional funds were obtained through large family donations that sincerely helped ease the burden of Mr. Nawir Ibrahim. In addition, additional funds are also obtained from the results of the granting of Muslimat NU.

On the day of the funeral, Mr. Nawir Ibrahim issued the following funds: o Costs related to bathing until burying the body (shroud, mat, wall are, etc.) : Rp. 150.000,- o Money for Kiaji (voluntary): Rp. 50.000,- o Sortana : Rp. 100.000,- o Consumption fee: Rp. 200.000,-On the day of the funeral, Mr. Nawir Ibrahim issued the following funds: Costs related to bathing until burying the body (shroud, mat, wall are, etc.): Rp. 150.000,Money for Kiaji (sincerely): Rp. 50.000,- Sortana: Rp. 100.000,- cost consumption: Rp. $200.000,-$ 


\section{First day of tahlilan}

On the first day of the funeral home the family looks busy as it prepares everything for the tahlil event later tonight. Each tahlilan Mr. Nawir Ibrahim provides 250 plates for both male and female mourners. And in the morning the women Ngombi' palappa (making cooking seasonings ranging from peeling spices to making pastries to be served to the alabet). Buy spices for cooking seasoning: Rp. 2.800.000,- Buy ingredients for pastries: Rp. 300.000,- Buy Blessing (instant noodles 4 dose @84.000) : Rp. 336.000,- Cost of consumption of kitchen people: Rp. 100.000,-

\section{Here's the cost for Tahlilan:}

$25 \mathrm{~kg}$ of rice: Rp. 250.000,- 5 kg chicken meat @40.000: Rp. 200.000,- 1 cigarette press: Rp. 90.000,- 3 dose of mineral water @ 12.000: Rp. 36.000,- Coffee, tea, and sugar: Rp. 50.000,- For each night, the cost spent for tahlilan and kitchen costs of Rp. 832.400,obtained from the total amount of the above costs divided by five days, should be seven days because there are exceptions Lo'tello' and To'petto'. at Lo'tello'(day three) and To'petto'(day four) The costs incurred for Lo'tello' and To'petto' are as follows: $50 \mathrm{~kg}$ of rice : Rp. 500.000,- $10 \mathrm{~kg}$ of beef: Rp. 1.100.000,- $5 \mathrm{~kg}$ of chicken meat: Rp. 200.000,300 eggs: Rp. 450.000,- 4 dose mineral water : Rp. 48.000,-1 cigarette press: Rp. 90.000,Coffee, tea, and sugar: Rp. 50.000,-

\section{On the day of Pa'polo, Nyatos,Nyataon, and Nyaebu}

The costs incurred for the above traditions are generally about the same. Here are the costs: $75 \mathrm{~kg}$ of rice: Rp. 750.000,- $5 \mathrm{~kg}$ of beef: Rp. $550.000,-10 \mathrm{~kg}$ of chicken meat: Rp. 400.000,- 200 eggs: Rp. 300.000,- 4 dose mineral water : Rp. 48.000,- 1 cigarette press: Rp. 90.000,- Coffee, tea, and sugar: Rp. 50.000,-

125 Thanks@10.000 : Rp. 125.000,-

\section{Mangaji Routine}

Mangaji tradition is done after the seventh day after Lalabet up to 40 days. Here are the costs incurred each night: Coffee, tea, and sugar: Rp. 20.000,-Tambul (usually fried food, cake, etc.): Rp. 30.000,- 


\section{Malem Ngin-tangin Sambi Nginep (Staying up late)}

This tradition is usually done by neighbors who stay at the funeral home, usually to comfort the funeral home so that it is not quiet. The cost is only in the form of coffee and sugar of Rp. 20.000,-

\section{Upacara Nyalenin Mayyid}

This activity is usually done when Pa'polo and Nyaebu, Mr. Nawir Ibrahim do this tradition to give happiness to the deceased. Usually in the form of clothing equipment from top to bottom, and nyaebu usually equipped with umbrellas, mats, paddles, glasses, pillows, and other equipment. The cost is Rp. 150.000,-

\section{Ajege Makam (Guarding the tomb) nyabek Kep-sekep (Talisman)}

This activity is carried out until the 40th day and is guarded from the eve of Maghrib until dawn. Usually guarded by two people. But now, the tradition has been abandoned and replaced by putting a piece to survive any disturbance, at a cost to the "smart person" of $R p .50 .000,-$

After all the needs are met, usually rice and sugar resulting from the administration of Lalabet is still left even up to $7 \mathrm{kwintal}, 5 \mathrm{kwintal}$ sold to cover the debts incurred during the implementation of tradition and the rest for the preparation of $P a^{\prime}$ polo.

This tradition is carried out as a hereditary form of ancestors that have existed since ancient times. But since the existence of Wali Songo, the tradition is polished with values in islamic teachings without erasing it entirely.

The financial management model of Lalabet tradition can be said to have an important role in the implementation of the Lalabet tradition. Because financial management is the main thing in every event that exists in Lalabet tradition. a good decision is made from good financial management, for example how Mr. Nawir Ibrahim manages the finances starting from the source of funding and costs to be incurred, and also how Mr. Nawir Ibrahim can pay off the debts incurred from the Lalabet tradition.

In Lalabet tradition, financial management of accounting equations can be applied, but in the application of financial management Lalabet tradition not all accounts contained in accounting equations are used. Because in the management of Lalabet tradition only requires expenditure and acceptance roughly only. 
Each transaction that occurs will affect the composition in the accounting equation (MT Ritonga and Yoga Firdaus 2007). Such transactions may change the arrangement of assets, liabilities, and equity. That is why each transaction needs to be analyzed, whether to change the composition of assets, capital, or liabilities, as well as how much each amount. In the financial management of Lalabet tradition, the analysis conducted is similar to the explanation above. Analysis conducted to find out how assets can increase and how to manage those assets so that other fulfillment can be fulfilled. Similarly, reducing the obligation on the financial management of Lalabet tradition is very concerned by aligning the goals or sacrifices made by Mr. Nawir Ibrahim in conducting events that become customary in the Lalabet tradition in Madura.

This procedure generally applies in the financial management tradition of Lalabet where transactions occuring in general are recorded simply as calculations on both income and expenses that occur during the tradition.

On the simple recording, Mr. Nawir Ibrahim usually records not based on the accounts contained in the accounting equation, but in accordance with the understanding of Mr. Nawir Ibrahim with a name and nominal that is easy to understand. In this procedure there is also no reporting in the form of financial statements as described in the accounting equation. In the procedure of financial statements Lalabet tradition is explained. Mr. Nawir Ibrahim will gather with relatives of Mr. Nawir Ibrahim and explain things that happened or transactions that occurred during the Lalabet tradition. The evidence that can be found in this procedure is usually a small record of Mr. Nawir Ibrahim in recording the income and expenses that occurred.

The financial management of Lalabet tradition, should be able to be a serious concern in its implementation. Because the success of the implementation of Lalabet tradition depends on how the financial management by Mr. Nawir Ibrahim. There needs to be a clear record of where the source of funds is obtained and what costs are incurred every day. This is done as an evaluation material in the implementation of tradition the next day. Because to make a good decision obtained from good management also so that everything that happens can be accounted for.

The financial model applied in Lalabet's finances, basically still takes practice in social life that is still classified as classical and simple. The practice of counting in income 
and expenditure has not reached the systemic modern level. This is as described by Suwardjono stating that in social life accounting is found, using terms that are still simple and not scientific, such as expenditure and income. The narrow understanding of accounting in social life is driven by the fact that the understanding of accounting around the point focuses on techniques and calculations.

Furthermore, subtansially Lalabet's financial model as in this study, is certainly influenced by the cultural, economic, and legal sectors as well as social institutions that take place in Babbalan Village. It is vital in turn that the development of accounting requires also an understanding of the historical in the place where the tradition takes place.

This understanding can then be understood that the financial model in the Lalabet tradition, is actually an accounting model that develops based on social construction in society. Where the accounting equation is Asset $=$ Capital + Debt + Donation.

Finance in the tradition of Lalabet Madura is not dim in the round of times. The logical consequences of the Madurese society since time immemorial indeed uphold the manners or ordinary Madurese call Tengka. This understanding that Madurese people channel in the details of tradition and community life.

As for the two things that Madurese do in the Lalabet tradition are: First, Tengka or in the financial tradition of Lalabet, every community is encouraged to distribute some of the wealth in the form of rice and money to Mr. Nawir Ibrahim. This motivation without needing to be asked, but has become a social structure that is regulated as social security for the future while relatives also die. Second, Please Help, this is the value of kindness. A goodness flows into a tradition that has been ingrained in society. The goodness in question is related to the relationship of Mr. Nawir Ibrahim, relatives and neighbors who help each other, both in terms of material and energy. Third, Alms, this part of understanding is the main point of the core of Lalabet, where everyone is reminded to channel some of the property owned to be distributed to others.

As for the conception please help and alms that will be the teachings of Islam in building social harmony. Islam emphasizes the principle of humanity as the foundation for building a peaceful and peaceful life among others. Therefore, in this Lalabet tradition, contained values that become a package of goodness can spring up in social life. In 
compressing this, where please help and alms that the community strengthened to the side of Mr. Nawir Ibrahim, be a obedient to Islam taught.

\section{CONCLUSION}

Lalabet's traditional financial management model includes the source of funds obtained, and expenditures made for the implementation of the Lalabet tradition. At the same time look at the possibilities that occur to be able to minimize debt. Assets or funds in the implementation of this tradition in Babbalan village are sourced from personal money, money or donated goods from the family, money from Muslims, and debts to people or taking goods from the store on credit. Expenditures that occur in the implementation of this tradition include costs for tahlilan and other traditions contained in the implementation of Lalabet tradition such as, mangaji, ngin-tangi samba nginep, nyalenin mayyid, and others. The difference between the capital earned and the expenditure can be used to cover the debt or as a preparation for the next tradition that relates to the Lalabet ceremony. Usually the amount of rice left over from Lalabet is mostly sold to pay debts and some of it for further preparation.

\section{REFERENCES}

Bogdan, Robert C. dan Biklen Kopp Sari. (1982). Qualitative Research for Education: An Introduction to Theory and Methods. Allyn and Bacon, Inc.: Boston London.

Kamayanti, Ari. dan Ahmar. (2019). Nurmala. TracingAccunting in Javanese Tradition International Journal of Religious Cultual Studies, 1(1), 15-24.

Moleong, J. Lexy. (2016). Metodologi Penelitian Kualitatif Edisi Revisi. Bandung : PT. Remaja Rosdakarya.

Randa, Fransiskus \& Daromes, E. (2014). Transformasi Nilai Budaya Lokal dalam Membangun Akuntabilitas Organisasi Sektor Publik. (Jurnal Akuntansi Multiparadigma, 5(3), 477-484.

Spradley, James P. (2007). Metode Etnografi Edisi ke-2. (Yogyakarta: Tiara Wicana. Suputra, I Dewa Gede Dharma. (2011). Refleksi Nilai-Nilai Akuntansi Dalam Organisasi Subak di Bali. Disertasi Program Doktor Ilmu Akuntansi Program Pascasarjana Fakultas Ekonomi Universitas Brawijaya Malang. 
Suwardjono. (2011). Teori Akuntansi Pekerayasaan Pelaporan Keuangan Ketiga. Yogyakarta: BPFE.

Thalid, Mohammad Anwar. (2017). The Importance of Accounting Investigation in Wedding Ceremonyin Gorontalo. Imperial Jurnal Of Interdisciplinary Research (IJIR), 3(1).

Zulfikar. (2008). Menguak Akuntabilitas di Balik Layar Kearifan Budaya Jawa. Jurnal akuntansi Keuangan 7(2), 144-150. 